Polska Akademia Nauk

Instytut Slawistyki

tel.: +48228267688

e-mail: dorota.rembiszewska@ispan.waw.pl

ORCID ID: https://orcid.org/0000-0003-0339-0879

\title{
Językowe oraz pozawerbalne wyróżniki XIX-wiecznego savoir-vivre'u i rozmów salonowych w opowiadaniu Stefanii Ulanowskiej Babie lato
}

Słowa kluczowe: etykieta językowa, dziewiętnastowieczna polszczyzna, kultura szlachecka wieku dziewiętnastego

Rozmowy salonowe, towarzyskie konwersacje to dosyć częsty wątek $\mathrm{w}$ dziewiętnastowiecznej literaturze pięknej i literaturze dokumentu osobistego. To także ważny temat, chętnie podejmowany w poradnikach dobrego zachowania. W XIX wieku, w okresie wielkich przemian społecznych, ekonomicznych, kulturowych na ziemiach polskich, nastąpiły również znaczące zmiany w zakresie etykiety językowej [por. m.in. Pawłowska 2016, Umińska-Tytoń 2001]. Kultura szlachecka przenosiła się powoli do miast (po powstaniu styczniowym wielu ziemian po konfiskatach majątków musiało opuścić swoje gospodarstwa), wytworzyła się także warstwa przedsiębiorców, urzędników, wolnych zawodów. Powszechniejszy stał się dostęp do oświaty, co spowodowało wytworzenie się nie tylko nowych wzorców zachowań ${ }^{1}$, ale także nowych reguł językowego obcowania [por. Umińska-Tytoń 2011]. Wzorce etykiety bardziej się uprościły i zdemokratyzowały, choć tradycyjne formy obyczaju towarzyskiego elit nadal w jakiejś mierze trwały w etykiecie salonowej (także mieszczańskiej, por. powieść Lalka Bolesława Prusa).

1 Te przyczyny wymienia m.in. Marek Cybulski omawiając uwarunkowania zmian w polskich obyczajach językowych na przykładzie wyrazów pan i sługa [Cybulski 1994]. 
Autorką opowiadania (powiastki) Babie lato, będącego materiałem źródłowym do analizy wskazanego $\mathrm{w}$ tytule zagadnienia, jest Stefania Ulanowska (1839-?). Pochodziła ona prawdopodobnie z terenu dzisiejszej Białorusi, na co wskazują informacje w tekście wspomnieniowym [Ulanowska 1912, 82] oraz liczne odniesienia w jej twórczości do obszarów białoruskich. S. Ulanowska jest m.in. autorką pracy Łotysze Inflant Polskich - opracowania dającego obraz życia mieszkańców Łatgalii (wschodnia Łotwa) w XIX wieku oraz kilkudziesięciu utworów, w tym o symbolice roślin i zwierząt, publikowanych m.in. w Bluszczu, Czasie, Tygodniku Ilustrowanym. Poza tym S. Ulanowska nadsyłała do czasopisma Wisła rysunki i zdjęcia obiektów architektonicznych ze znanych sobie miejsc lub tych, które miała okazję zobaczyć podczas badań terenowych. W tomie 5. [Wista, 1892, z. 3, s. 671] znalazł się rysunek chaty ze wsi Dwornia ${ }^{2}$, gmina Moszkany (brus. Машканы), powiat sienneński, gubernia mohylewska, a w tomie 6. Wisty [Wista, 1893, z. 2, s. 384] zamieszczono, również z tej miejscowości, fotografię przedstawiającą tok 'budynek, w którym młócono zboże', co dobitnie potwierdza związki tej autorki z obszarami wschodniosłowiańskimi.

Babie lato to 21-stronicowy tekst, prawdopodobnie nigdzie niedrukowany $^{3}$. Nie znamy daty jego powstania, ale można przypuszczać, że został napisany w latach dziewięćdziesiątych XIX wieku, bo na tę dekadę przypada największa aktywność pisarska S. Ulanowskiej. Utwór ten, choć o niewielkiej wartości literackiej (widać nieporadność warsztatową, nieumiejętność budowania narracji), stanowi ciekawe świadectwo typowej rozmowy salonowej czasów fin de siècle'u.

Opowiadanie S. Ulanowskiej, osnute na wielowątkowych dialogach prowadzonych w ,salonie, którego okna zwrócone były na jeden z placów warszawskich" [BL k. 1], to historia odnowionej po latach miłości. Głównymi uczestnikami rozmów są Amelia, Klara, Iwo, którzy mieszkali dawniej w Międzyrzeczu na Podolu i po latach spotkali się w Warszawie. Niejako na marginesie pojawiają się wypowiedzi skierowane do dzieci Klary i do służącej.

Okazją do rozmowy jest wizyta towarzyska. Zgodnie z zasadami ówczesnego bon tonu stanowiła ona konieczny element współżycia społecznego:

\footnotetext{
2 Obecnie wieś nie istnieje.

3 Tekst opowiadania znajdzie się w przygotowywanej przeze mnie książce na temat twórczości Stefanii Ulanowskiej.
} 
Odwiedziny są jedną z najpotrzebniejszych rzeczy w towarzyskich stosunkach: w nich to jest źródło mniejszej lub większej zażyłości, jaka się pomiędzy ludźmi wyradza, i one są prawdziwemi ogniwami społecznego łańcucha. Zaniedbywanie ich, byłoby wskazaniem się na życie odosobnione, bo chwilowe zbliżenie w skutek potrzeby albo konieczności jest krótkotrwałem i żadnej nie wywołuje wzajemności. [...] Odwiedziny można podzielić na cztery klasy: ceremonialne, obowiązkowe, przygodne, i przyjacielskie [Miłkowski 1852, 63-64].

Jednocześnie zasady dobrego zachowania regulowały sposób prowadzenia konwersacji, w zależności od typu rozmówcy. Sztuka rozmowy towarzyskiej była ważnym elementem ówczesnej kompetencji komunikacyjnej ludzi z wyższych sfer, wymaganą przepustką do uczestnictwa w kulturze. W jednym z XIX-wiecznych poradników zatytułowanym $O$ towarzyskości i obcowaniu z ludźmi znalazły się na przykład rady, nie tylko jak rozmawiać z osobami reprezentującymi różne stany, ale także z osobami wyróżniającymi się określonymi cechami charakteru, a więc

z samolubami, z ludźmi frasobliwemi, niewesołemi i do złego humoru skłonnemi; z ludźmi nałogiem się rządzącemi, z mało mądremi i nie dosyć znajomości świata posiadaiącemi, z słabego i bojaźliwego charakteru ludźmi, mężczyznami i kobietami wystawnie czułemi, czyli przeczulonemi, z ludźmi próżnością nadętemi i wszystkim bez braku podobać się pragnącemi, z ludźmi fałszywemi, złośliwemi, zazdrościwemi i zawziętemi [O towarzyskości 1819].

Dla zwyczajów towarzyskich bardzo ważne pozostaje określenie rodzaju relacji i więzi łączącej rozmówców. Na podstawie tego kryterium możemy przyjąć, że w omawianym tekście S. Ulanowskiej występują cztery rodzaje sytuacji konwersacyjnej:

1. układ symetryczny (rozmówcy mają równorzędny status społeczny i porównywalna rangę pragmatyczną), który tworzą dwie kuzynki (Amelia i Klara) oraz mężczyzna (Iwo); pochodzą oni z tego samego środowiska ziemiańskiego, reprezentują właściwie ten sam status społeczny;

2. układ symetryczny o znamionach asymetrycznego, dotyczący rozmowy między mężczyzną a kobietami (pozycja rozmówcy - kobiety jest osłabiona przez kulturową dominację mężczyzny, co implikuje jednostronną dążność do skracania dystansu, niejaką protekcjonalność w sposobie bycia itp.) - Iwo, Amelia, Klara;

3. układ asymetryczny o mniejszym stopniu dystansu, gdzie uczestnikami rozmowy są matka i dzieci (asymetria wynika z nierównorzędnej pozycji dziecka w rodzinie, szerzej - wobec świata dorosłych);

4. układ asymetryczny pełny, w której pani domu zwraca się do służącej (pozycja rozmówcy jest zdefiniowana przez relację władzy, zależności służbowej, hierarchii stanowisk itp.). 
Jak widać, w dwóch pierwszych sytuacjach mamy do czynienia z rozmowami typowo nieoficjalnymi, co niesie za sobą użycie swobodniejszych form grzecznościowych, właściwie zredukowanie dystansu. Rozmowa ma charakter spontaniczny, wyraźnie widać, że uczestnicy wizyty cieszą się ze spotkania.

Pierwsza sytuacja dotyczy rozmowy dwóch kobiet równych sobie, jeśli chodzi o hierarchię społeczną. Jest to zwykła pogawędka osób, które dawno się nie widziały, a w przeszłości wielokrotnie się spotykały, ich rodziny spędzały wspólnie czas. Nie znajdziemy więc tu zdawkowych formuł wygłaszanych podczas obowiązkowych wizyt, ani wyszukanych słów, wtrąceń obcojęzycznych. Pojawiają się natomiast zwroty i wyrażenia o charakterze emfatycznym, implikujące bliską więź łączącą rozmówców: „znałyśmy się dobrze, byłyśmy z sobą jak siostry!" (Klara do Amelii) [BL k. 2]. Bliskość relacji, brak dystansu kuzynek wobec siebie sygnalizują nie tylko pieszczotliwe formy adresatywne (nawet tzw. afektonimy): „Amelko! Więc to ty jesteś, najdroższa moja!” [BL k. 2], „moja Klaro kochana”, „moja droga” (BL k. 10), ale również akt pozawerbalny: „I rzuciła się jej na szyję, a wśród uniesień posypały się z obu stron wykrzykniki i powstał taki gwar radośny" [BL k. 3].

W rozmowach bohaterów pojawia się jeszcze jeden charakterystyczny sposób zwracania się do rozmówcy, a mianowicie używanie nazw pokrewieństwa w funkcji adresatywnej (przetrwało ono do połowy XX wieku, por. Umińska-Tytoń 2001, 88), co służyło z kolei podkreślaniu więzi rodzinnych. W opowiadaniu Ulanowskiej ze względu na ograniczony krąg bohaterów nie ma co prawda zbyt wielu konkretnych nazw stopni pokrewieństwa, ale używa się wyrazu określającego w sposób ogólny związki rodzinne. Iwo zwraca się do Klary „kuzynko kochana” [Bl k. 18], „Kuzynka Klara nam wybaczy” [BL k. 19] oraz Klara do Iwona: „Jakież tu plany macie do ułożenia, piękny kuzynie?" [BL k. 18].

Zwraca uwage wielokrotne powtarzanie się w formach adresatywnych zaimka mój. W tym układzie symetrycznym zaimek posesywny implikuje serdeczność. Dzisiaj jest on odbierany jako protekcjonalny, w wieku XIX mógł pełnić funkcję wykładnika relacji familiarnych (choć w niektórych przypadkach bywał wyrazem wyższości nad rozmówcą). Wzmocnienie wrażenia pozytywnego stosunku do rozmówczyni daje forma deminutywna imienia: „moja Klaruńciu!” [BL k. 3], „moja Amelko” [BL k. 5], a poczucie bliskości użycie w bezpośrednim sąsiedztwie zaimka posesywnego i osobowego: „A moja ty droga, a moja ty kochana” [BL k. 3].

W kolejnej sytuacji konwersacyjnej, w której uczestniczą kobiety i mężczyzna, istotne wydają się struktury składniowe zawierające formy adresa- 
tywne, które są kontynuacją stanu polszczyzny z XVIII wieku [por. Wojtak 1992, 36]. Chodzi tu o formy zaimka ty w połączeniu z formą 2 osoby lp. czasowników zamiast spodziewanego pan/pani z 3 os. lp. czasownika. Tej poufałej (zaimek grzecznościowy uzgodniony jest ad sensum nie ad formam) formuły adresatywnej używano jedynie w kontaktach familiarnych, wśród przyjaciół oraz przy zwracaniu się do dzieci [por. Umińska-Tytoń 2011, 143]. W tekście S. Ulanowskiej odnajdujemy przykłady połączeń formy 2 os. lp. z elementem pan mające na celu redukcję dystansu. Ten sposób zwracania się charakteryzował kontakty symetryczne, dające poczucie traktowania uczestników rozmowy jako kogoś swojego, przynależącego do tej samej społeczności. Stąd ich obecność w omawianym opowiadaniu: „Mnie się pan spytaj, to się prędzej dowiesz prawdy, wtrąciła Klara” [BL k. 10]; Amelia do Iwona: „Wątpię jednak, czy pan sobie przypomnisz" [BL k. 10]; Klara do Iwona: ,spodziewam się p. Iwonie, że pan już nie pójdziesz do teatru” [BL k. 12], „Nie wiesz pan jak tam się bratu memu powodzi?” [BL k. 12], „Powiedz pan proszę" [BL k. 13, k. 14] „Pan się nie chwal, p. Iwonie" [BL k. 17].

Z kolei, kiedy rozmawiają Amelia z Klarą, używają tylko formy 2 os. lp. czasownika (lub wykładnika 2 os. dołączonej do innej części mowy), co wskazuje oczywiście na dużą zażyłość, np. „Pociesznaś ty z temi swojemi zasadami!”, „zapomniałaś, że moje zasady nie pozwalają mi czekać do jutra!”, „pocożeś zadawała sobie tyle trudu?”, „śmiałabyś się, gdybyś słyszała" [BL k. 12].

W sytuacji rozmowy Iwona z Klarą warto dostrzec kolejny przejaw etykiety językowej, jakim jest dodatnie wartościowanie partnera, a więc prawienie komplementów. Komplement był niejako obowiązkowym elementem słownych zabiegów w staraniach o względy partnerki. Zbigniew Kuchowicz, który opisał wzory miłości staropolskiej, zaznaczył, że „komplementowanie kobiet występowało najsilniej w czasach baroku. Podczas wesel gdańskich odczytywano wiersze, w których pannę młodą, choćby była najszpetniejsza, nazywano piękniejszą od Wenery albo Heleny" [Kuchowicz 1982, 327]. W XIX wieku nie przybierały komplementy takiej wyszukanej i przesadzonej formy, ale były one obecne w czasie rozmów między kobietami i mężczyznami, co znajduje potwierdzenie chociażby w ówczesnych pamiętnikach [Umińska-Tytoń 2004, 709]. Nie ma tu już sentymentalnej czułostkowości (przejawiającej się w użyciu nadmiernej liczby deminutiwów), gdzie mężczyzna „padał do nóżek” i „całował rączki i nóżki szanownej pani” oraz

\footnotetext{
4 O wyrazie pan jako składniku form adresatywnych w historii polszczyzny por. Sikora 2011, 2013.
} 
zachwycał się jej ślicznymi ząbkami. Franciszek Betlejczyk w artykule $O$ języku towarzyskim [1862] potępia tego typu frazy. XIX-wieczne poradniki dobrego zachowania również przestrzegają przed nadmiernym komplementowaniem, zalecając niejaką wstrzemięźliwość w tym względzie:

Trąci to dzisiaj złym wychowaniem, nudzić kobiety temi błahemi komplementami, na jakie niegdyś zezwalała galanterya francuzka. Jakkolwiek spotykają się jeszcze (chociaż w małej liczbie) lekkomyślne kobiety, dla których one powab mieć by mogły, większa ich część przyjmuje je z pogardą, bo ich umysł wykształcony nie dozwala im znaleść uciechy w takowych małościach [Miłkowski 1852,145$]$.

W opowiadaniu S. Ulanowskiej Iwon komplementuje Amelię w sposób taktowny, właściwy ich bliskim relacjom. Należy zdawać sobie sprawę, że Iwon to mężczyzna dojrzały, mający świadomość swojego wieku i niestosowności w przesadnym wyrażaniu uczuć i dlatego jego wypowiedź nie jest przykładem przesadnie ozdobnej oracji. Wypowiedź Iwona pozostaje w zgodzie z obowiązującymi kanonami prowadzenia rozmów w owym czasie. Bez zbędnej afektacji uwypukla zalety kobiety, którą się interesuje, używając w sposób umiarkowany zdrobnień i przymiotników, w tym melioratywnych:

pamiętam panią doskonale jako młodziuchną panieneczkę uderzającej powierzchowności, tylko że to spotkanie jest dla mnie prawdziwą niespodzianką! [...] kiedyśmy dopiero co mówili o niej, tom wspominał właśnie, jakeś pani tańczyła na imieninach ciotki w sukience białej z bławatkami świeżemi we włosach. Jest to jeden z tych wdzięcznych obrazków, które zostają w pamięci! [BL k. 11].

Swego rodzaju komplementem jest rozbudowany zwrot formuły powitania Amelii przez Iwona:

Witam więc panią jako dawną znajomą i czuję się nadzwyczaj szczęśliwym, że ją spotykam po tylu leciech! [BL k. 11].

W rozmowie Iwona z Klarą pojawia się w czasie wymiany zdań rodzaj dobrotliwego pouczenia związanego z prowadzeniem rozmowy, odwołania się do funkcjonującej etykiety (pomniejszanie ewentualnych słabości, przewinień odbiorcy należy po dziś dzień do kluczowych reguł polskiej grzeczności):

Jak to można przyznawać się do jakiegoś wieku, będąc kawalerem? zawołała Klara. Trzeba być dyskretnym i kwestyi takich nie poruszać! [BL k. 13].

Pewne zachowania etykietalne, którym nie towarzyszą utarte formuły, można zauważyć w dialogu Amelii z Klarą w momencie spotkania. Wymieniają 
się serdecznościami, potem informacjami, co się zdarzyło w ich życiu w ostatnich latach. Pozwalają sobie nawet na coś w rodzaju wyrzutów, napomnień, które w istocie są wyrazem życzliwości i troski. To kolejny dowód na istniejącą między nimi (wspomnianą wyżej) relację solidarności:

- Bardzo to poczciwie z twojej strony, moja, Amelko, ale czemużeś prosto nie do mnie zajechała z kolei?

- Jakto? Po tak długiem niewidzeniu się? A możebyś nie była mi rada?

- A jakżeś nierada! A to dopiero ceremoniantka z ciebie! [BL k. 5].

Zupełnie inną sytuację rozmowy tworzą matka i dzieci. Ten typ relacji asymetrycznej rządzi się swoimi prawami. Konieczność zachowania dystansu nie wyklucza serdeczności i czułości. Klara zwraca się do swoich dzieci używając zdrobnień imion w formie wokatywnej: „Julciu! Stasiu! Karolku! [...] a pójdźcież tu!”, „Julciu, powiedz Katarzynie, niech zaraz podaje kawę" [BL k. 3].

Z kolei córka Klary, kierując do matki pytanie, posługuje się nazwą stopnia pokrewieństwa + formą 3 os. lp., co było wykładnikiem szacunku i poważania osób niżej usytuowanych względem usytuowanych wyżej [por. Umińska-Tytoń 2011, 143], z czym tutaj mamy niewątpliwie do czynienia: „Czy Mama kogo innego się spodziewała?” [BL k. 1]. Ta forma utrzymała się do końca XX wieku np. wśród potomków drobnej szlachty północno-wschodniego Mazowsza [Rogowska 2007: 269].

Czwarta sytuacja konwersacyjna - także asymetryczna - dotyczy sposobów zwracania się pani domu do służącej. W Księdze obyczajów towarzyskich M. Rościszewskiego, do czytelników kierowana jest przestroga: „Jeżeli mamy jedną sługę, to wołamy na nią po imieniu [...]. Sługi dorosłej nigdy nie należy nazywać zdrobniale" [Rościszewski 45].

Tej zasady przestrzega bohaterka opowiadania Babie lato. Gospodyni zwraca się do służącej po imieniu i używa formy imperatywnej, wzmocnionej partykułą „Katarzyno, Katarzyno!!! A pójdźże otwierać prędzej!" [BL k. 1].

Kontekst dla rozmów salonowych, prowadzonych według obowiązujących reguł, tworzą akty niewerbalne. Ich obecność jest również zaznaczona w tekście S. Ulanowskiej.

Do dobrego tonu należało częstowanie przybyłych gości, namawianie (czasem usilne) do jedzenia i picia.

Dlatego Amelia, jako dobra gospodyni, na wieść o spodziewanych gościach, rozdysponowuje domownikom czynności, aby przygotować odpowiedni poczęstunek: 
Julciu, powiedz Katarzynie, niech zaraz podaje kawę, a ty sam pójdź do śpiżarki, nałóż na spodeczki cztery gatunki konfitur, wiesz tych najlepszych: agrestu, truskawek, róży i jeszcze tam coś czwartego - może gruszek! [...] Daj też makowników i orzeszków smażonych, bo ciocia dawniej lubiła to wszystko... A ty Stasiu pobiegnij do cukierni po świeże sucharki, ty Karolku leć do przekupki po pomarańcze! I prędko mi się zwijać, żebyśmy nie czekały długo! [BL k. 3].

Następny element wymagany przez zasady dobrego zachowania to całowanie w rękę . Nazywany po latach cmok-nonsensem ${ }^{6}$, wywodzący się jeszcze z kultury rycerskiej, gest całowania dłoni kobiety przez mężczyznę był w XIX wieku ${ }^{7}$ należytym wyrazem szacunku dla kobiety.

W opowiadaniu grzecznościową formułę słowną powitania dopełnia akt pozawerbalny, niezbędny w utrzymaniu etykietalnego zachowania: „Po tych słowach podniósł do ust rękę, którą mu podała na powitanie i ucałował z zapałem" [BL k. 10].

Konieczność całowania w rękę dorosłych dotyczyła także dzieci: „Julciu! Stasiu! Karolku! [...] Ucałujcie rączki cioci!” [BL k. 3].

W opowiadaniu występuje także inny gest - uchylenia kapelusza (tylko chłopstwo musiało się kłaniać do ziemi, „zamiatając ziemię” czapką) na widok mijanej osoby, świadczący o szacunku wobec niej. W poradniku dobrych manier wydanym w 1823 r. autor poucza:

Zdjęcie kapelusza iest pokłonem powszechnie u mężczyzn przyjętym, przy czem baczyć wypada, ażeby ręka nie oddalała się daleko od ciała, co jest rzeczą staroświecką, a czasem niemało śmiechu wzbudzającą [Człowiek 1823, 75].

W Babim lecie narratorka także wskazuje, że uchylenie kapelusza znamionuje ludzi kulturalnych:

[Iwo] Zatrzymał się, aby jej zostawić drogę do przejścia z grzecznością właściwą wszystkim ludziom dobrze wychowanym, uchylił kapelusza w chwili, gdy go mijała [BL k. 10].

5 Jednocześnie ówczesne poradniki dobrego zachowania odradzały całowanie się: „Całowanie jest zwyczaiem, które by już od dawna, a przynaymniej w dobranych towarzystwach, zupełnie zarzucić należało, bowiem nigdy oddech innej osoby przyiemnym być niemoże, kiedy przeciwnie, jest szkodliwy, nie od rzeczy przeto będzie prosić o zupełną zagłade iego, a ieśli iuż damy umizgom chętne, koniecznie całusów pragną, niechżeby przynaymniey mężczyzni z pośród siebie na zawsze wyrugowali. bowiem niechay kto chce co mówi, obyczay ten zniewiaściałością trąci [Człowiek 1823, 104].

6 Takie określenie, modne w czasach Polskiej Rzeczpospolitej Ludowej, wprowadziła Janina Ipohorska „Jan Kamyczek”, autorka poradnika Grzeczność na co dzień (1955).

7 Jak podaje Anna Gałęziowska-Krzystolik, zwyczaj całowania dłoni kobiety przez mężczyznę przyszedł do nas z Europy zachodniej i na dobre zaczął obowiązywać w towarzystwie w wieku XIX [Gałęziowska-Krzystolik 2016, 62]. 
Podane wyróżniki etykiety językowej i pozajęzykowej w tekście Babiego lata są uzupełnieniem materiałowym rozważań na temat savoir-vivre'u w wieku XIX i potwierdzają zmiany, jakie zaszły w tym czasie w zakresie grzeczności w porównaniu z okresem staropolskim. Stanowią one także świadectwo dawnej kultury szlacheckiej, przeniesionej do domów mieszczańskich, której elementy zachowały się zarówno w sposobie odnoszenia się do rozmówcy, jak i we wzorach językowych realizowanych w sytuacji swobodnej konwersacji salonowej. Dzięki lekturze opowiadania S. Ulanowskiej można prześledzić, ile z ówczesnych zwyczajów towarzyskich przetrwało aż do współczesności, a które bezpowrotnie zanikły. Do dzisiaj zachowały się niektóre formuły grzecznościowe (np. zdrabnianie imion w stosunku do dzieci), konieczność zaznaczania szacunku wobec rozmówcy, częściowo zwyczaj prawienia komplementów kobietom. Całowanie w rękę kobiet, niegdyś obowiązkowe, dziś choć akceptowane w niektórych kręgach, w środowiskach feministycznych bywa uznawane wręcz za przejaw naruszania prywatności. W niektórych domach przestrzegana jest reguła okazywania gościnności przybyłym. Porównanie stanu z końca XIX wieku z tym, co możemy obserwować współcześnie, bardzo wyraźnie wskazuje na duże rozluźnienie norm etykietalnych, zarówno w warstwie językowej, jak i pozawerbalnej ${ }^{8}$, skracanie dystansu i coraz mniejsze przywiązanie do dawnych zasad bon tonu.

\section{Źródła}

BL - Archiwum Państwowe w Warszawie, Zbiór Korotyńskich, sygn. 2622, mikrofilm, Stefania Ulanowska, Babie lato.

\section{Literatura}

Betlejczyk F., 1862, O języku towarzyskim, [odb. z „Czasu”], Kraków.

Cybulski M., 1994, Pan i stuga. Niektóre spoleczne uwarunkowania zmian w polskich obyczajach jezykowych, [w:] Uwarunkowania i przyczyny zmian jezzykowych: zbiór studiów, red. E. Wrocławska, Warszawa, s. 31-39.

Człowiek wielkiego świata, czyli Nauka, jak się na wielkim świecie w pożyciu towarzyskiem zachować należy, 1823, Lwów, [online] https://sbc.org.pl/dlibra/ publication/9296/edition/8656/content?ref=desc [11.05.2019].

8 Dobitnym przykładem rozluźnienia rygorów językowej etykiety jest zestawienie form grzecznościowych, używanych współczenie, w Stowniku językowego savoir-vivre'u (Marcjanik 2014). 
Gałęziowska-Krzystolik A., 2016, Językowa grzeczność polska i francuska w epoce globalizacji z perspektywy glottodydaktycznej, Praca doktorska, Katowice, https://www.sbc.org.pl/publication/274577 [dostęp 11.05.2019].

Ipohorska Janina [Jan Kamyczek], 1955, Grzeczność na co dzień, Warszawa, kolejne wydania: 1956, 1959, 1969, 1972, 1974, 1978.

Kuchowicz Z., 1982, Miłość staropolska. Wzory - uczuciowość - obyczaje erotyczne XVI-XVIII wieku, Łódź.

Marcjanik M., 2014, Stownik językowego savoir-vivre'u, Warszawa.

Miłkowski J.K., 1852, Prawidła obyczajności ku zachowaniu uprzejmych w świecie stosunków, Kraków.

O towarzyskości i obcowaniu z ludźmi. Część II, 1819, Warszawa, [online] https:// www.sbc.org.pl/dlibra/publication/4085/edition/3794/content?ref=desc [11.05.2019].

Rogowska A., 2007, Etykieta językowa przedstawicieli drobnej szlachty pótnocno-wschodniego Mazowsza, „Prace Filologiczne”, t. LII, s. 269-279.

Rościszewski M., [br.], Księa obyczajów towarzyskich. Kodeks wypróbowanych przepisów..., Lwów-Złoczew.

Sikora K., 2011, Z panem i kmieciem po świecie - o tradycji i wspótczesności w zwracaniu się do drugich, „LingVaria”, t. VI, nr 2 (12), s. 79-88.

Sikora K., 2013, Od prosze taski pana do prosze pana, „Język Polski”, R. XCIII, z. 4 , s. 287-298.

Ulanowska S., 1912, Historja dziewięciu i pół dusz (z pamiętnika starej obywatelki), [w:] Z okolic Dźwiny. Ksiega zbiorowa na dochód Czytelni Polskiej w Witebsku, Witebsk, s. 82-84, [online] https://www.sbc.org.pl/dlibra/show-content/ publication/edition/21617?id $=21617 \&$ from $=\mathrm{FBC}$ [11.05.2019].

Umińska-Tytoń E., 2001, Co wiemy o zasadach salonowej konwersacji? (Na podstawie pamiętników $i$ kodeksów obyczajowych z drugiej połowy XIX w.), [w:] Między kultura „niska” a „wysoka”. Zjawiska jezykowe, literackie, kulturowe, red. M. Korytkowska, Z. Darasz, G. Minczew, Łódź, s. 299-307.

Umińska-Tytoń E., 2004, Komplementy, czyli piękne słówka, [w:] Piękno materialne, piękno duchowe, red. Anna Tomecka-Mirek, Łódź, s. 705-714.

Umińska-Tytoń E., 2011, Polszczyzna dziewiętnastowiecznych salonów, Łódź.

Wojtak M., 1992, Wybrane elementy staropolskiej etykiety językowej, [w:] Język a kultura. Tom 6. Polska etykieta językowa, red. J. Anusiewicz, M. Marcjanik, s. $33-40$. 


\title{
LINGUISTIC AND NON-VERBAL FEATURES OF $19^{\text {th }}$-CENTURY SAVOIR-VIVRE AND LIVING ROOM CONVERSATIONS IN THE SHORT STORY BABIE LATO BY STEFANIA ULANOWSKA
}

\author{
ABSTRACT
}

Key words: language etiquette, nineteenth-century Polish, nobility culture of the nineteenth century

The article discusses linguistic and non-verbal features of $19^{\text {th }}$-century savoirvivre.

Babie lato [Indian Summer] by Stefania Ulanowska (1839-?), the source text under scrutiny, is a 21-page short story, which has most probably never come out in print.

There are four conversation situations in the text: 1) a symmetrical setup (the interlocutors have equal social status and comparable pragmatic rank), 2) a symmetrical setup with asymmetrical features, related to the conversation between a man and a woman, 3) a less distanced asymmetrical setup, where the participants of the conversation are the mother and children, 4) a full asymmetric setup, in which the mistress of the house addresses the maid.

The short story moreover features non-verbal etiquette features, such as a man tipping over his hat when he sees a woman and a man kissing a woman's hand.

The characteristics of etiquette observed in Babie lato are a supplement to the deliberations on savoir-vivre in the 19th century and confirm the changes that took place at that time in terms of courtesy in comparison with the old Polish period. They are also a testimony to the old culture of the nobility, transferred to bourgeoisie houses. 